\title{
Translating Roald Dahl's Fantastic Mr. Fox to Hindi: A Case Study of Translated Children's Literature
}

SUSHMITA PAREEK

\begin{abstract}
Children's Literature has been marginalised because of the reading audience's age. Translation and Translation Studies suffer from a similar fate due to the concept of authorship and originality that has governed the field of arts and aesthetics. Children's stories serve not only to enhance the reader's language skills but also plays a role in the development of empathy and other moral values which has been identified as major didactic role of this genre. Since the reading audience is still learning the language, a word-to-word rendering of the source language will transform the word play, jingles, cultural proverbs and jokes into incomprehensible content.
\end{abstract}

This paper is a working model of translating children's literature and discusses the problems of translating from English to Hindi. For the present research Roald Dahl's novel "Fantastic Mr. Fox" was translated from English to Hindi. The author's official website states that his stories have been translated into 58 languages around the world including Marathi, Tamil and Bengali. ${ }^{1}$ Hindi is one of the most spoken languages in India, but since there was no translation of Roald Dahl's stories available in Hindi (to the author's best knowledge), the first objective of research was to translate his novels. The paper addresses the debate between foreignization and domestication, between fidelity towards the author and fidelity towards the readers. It also discusses the quality of anthropomorphism which is special to children's stories but

\footnotetext{
${ }^{1}$ roalddahl.com: The official website of the author contains information regarding publishing houses, publishing years and translation of the author's works in different languages.
} 
represents the cultural symbolic meaning attached to animals. The questions raised by the study are: how does the translator bridge the gap between the foreign text and his readers? Does domestication strategy do justice to the author's imagery and topographical descriptions? Is foreignization essential in order to introduce the readers to far off lands?

Keywords: Children's Literature, Translation, Fidelity, Cultural Symbolism.

\section{Introduction}

A very unique quality of texts for children is that they are read aloud by the adults for children who cannot read and are still learning the language. The texts contain special features like rhymes, songs, repetition (and echo terms), frequent line breaks, smaller sentences and illustrations. Keeping in context the above features, a translator decides the variations in tempo, word stress, rhythm, time, and pauses. The complexity of the text is its aesthetic quality that communicates and helps the reader/listener draw images with restricted sentence lengths and vocabulary (which is comprehensible by the youngsters). The willingness of the youngsters to read a text is governed by the comprehension factor, many a times the texts are separated into different genres based on this factor.

For a long time, children's literature was assumed to be simplistic and lacking literary aesthetic quality compared to the larger canon of literature classics. Natalie Babbitt (1973: 157) discusses the language use by questioning this assumption:

"A children's book uses simple vocabulary geared to the untrained mind? Compare a little Kipling to a little Hemingway and think again. Opening sentence of $A$ Farewell to Arms: 'Now in the fall the trees were all bare and the roads were muddy'. Opening sentence of How 
the Rhinoceros Got His Skin: 'Once upon a time, on an uninhabited island on the shores of the Red Sea, there lived a Parsee from whose hat the rays of the sun were reflected in more-than-oriental splendour'. So much for that!"

Works like Alice in Wonderland by Lewis Caroll (first published in the year 1865), German text first published in 1816, Nutcracker and the Mouse King by E. T. A. Hoffman (2007) from the Modern Age contradict the assumption. Texts by Jane Austen, Charlotte Bronte, Charles Dickens and other major writers of English Literature are widely read by children (abridged version of the classic texts, which is another field of enquiry in the genre). Thus, the presumption that children's literature lacks the literary qualities is incorrect.

It is important to note that the genre has rich use of vocabulary in the forms of word play, rhyme and rhythms which not only showcase skilful use of language but also phonetic quality. For example; Roald Dahl's novels contain a vast number of denominal verbs which render onomatopoeic qualities denoting actions, terms like tunnelled, foggiest, crunched, chortled and chuckled. The word play is not only to make reading interesting for children but also renders additional vocabulary and phonetic delight that helps them in acquiring the language skills. The pedagogical function of the literature especially read by children denotes learning of the language (as they are still acquiring linguistic working knowledge) and learning of life lessons (as they lack experience of the sociocultural setting they are a part of).

Riita Oittinen (2014: 35) draws a difference between texts being translated for young readers and the ones aimed for adult readers on the basis of the style the translator adopts on the levels like; vocabulary, sentence structure, setting and image of 'child' (depending on the translator's understanding of the 
term and age). The translated text hence, is a product of the choices that the translator makes on the above denoted levels, adapts a strategy for his 'marked audience'.

There have been numerous ways in which critics, readers, librarians and publishing houses distinguish the genre of children's literature but the boundaries are porous and criteria for judgement ever changing. As David Rudd (2012: 19-29) remarks in his introduction to Routledge companion to Children's literature:

"this being (child) can be reduced to a psychological profile or even to its biological and anatomical features but such depictions fail to capture the fact that children exist only within particular sociocultural contexts, and these might envisage children as innocent and godlike, or as innately evil, or simply as pint sized adults. The artefacts produced for these children will vary accordingly."

Following is an example of the impact translation can have, as Aladdin and Ali Baba and Forty Thieves have become frequently represented stories in films and stage adaptations. The stories from Thousand and One Nights have numerous cartoon adaptations for children recurrently translated and represented. For instance, the movie Aladdin directed by Guy Ritchie which released in 2019 was a 'live-action adaptation' of the 1992 Aladdin movie by Disney Production house whose fan base mostly comprises of children.

Thousand and One Nights commonly known as Arabian Nights is a set of folk tales in Arabic which belongs to the Islamic Golden Age ( $8^{\text {th }}$ to $14^{\text {th }}$ century). Antoine Galland translated the text to French in early $18^{\text {th }}$ century. Interestingly rather than the core text which was Arabic and had Indian and Persian roots, translators that followed Galland chose to read his version for reference. Which meant that many oral tales 
that he remarked of having heard, while in the city were not part of the Hazar Afsane (literally meaning 1000 tales in Arabic) but were included in his French version of the text. For example, the tale of Aladdin which has a Disney cartoon series based on it besides movies and shows in different languages was not a part of the actual Thousand and One Nights. Ali Baba and Forty Thieves was also added by Galland in his copy, they are now referred to as 'orphan tales'. Jorge Luis Borges (2000: 34-48) discusses in detail all the translated versions of Thousand and One Nights in English in his essay The Translators of Thousand and One Nights. The Orphan tales added by Antoine Galland have become recurrently represented, the translation made an everlasting impact on the representation of 'Oriental' and 'East', introducing the 'foreign' to the English readers (especially children through cartoon productions).

\section{The Intended Reader}

What lies at core to the topic, is the idea of what is a 'child'. It is an ever evolving term which not only addresses the biological age but also mental and emotional age of beings.

The literary movement, New Historicism puts such definitions, texts and terms in contexts, it seeks to understand the hierarchy of literature and where different genres lie at a particular point of time in history. It thus follows; there is always a gap between what was historically understood as a part of such literature and the contemporary texts that constitute the canon. Few texts have crossed the boundaries of adult literature to become a part of children's literature. A classic example is the abridged versions of canonical texts by English authors like Charles Dickens, Jane Austen, and Charlotte Bronte etc.

The image of the child 'the intended reader' (in context of the writers who write for children) is different in different parts of 
the world at different points of time in history. This becomes the key to understanding how the author views the intended reader (child) while writing for them. The evolution of the genre is based on the development of this idea of child and childhood as a separate stage in human life.

Historically, the concept of childhood is a very recent one (English), during late $17^{\text {th }}$ century John Locke (1860) introduced the concept of Tabula Rasa. It considered the 'mind' as a blank state at birth, this blank state was then filled with social and cultural norms and code of conduct during the course of growing up. The age category gained special attention and recognition during and after Enlightenment and romanticism in England (18 ${ }^{\text {th }}$ century).

There was a divide between the practise of child labour and exploitation during the booming period of Industrialization and the high ideals of childhood as an age of innocence. The poetry of William Blake creates a clear distinction between the state of children in England and his own idea of 'age of innocence'. His Songs of Innocence and of Experience was an illustrated copy of poetry subtitled in its second edition as Shewing the Two Contrary States of the Human Soul. The songs were written to create a contrary image between the child and the adult, heaven and hell, innocence and sin of knowledge (experience), nature and industrialisation.

In India the legal age to vote is 18 ; the age varies from 15 to 21 in different countries. This age of cross over can be used as a tool of assessing the ideals of childhood in the society. The age has varied through the last century and also varies based on the region and historical background of the countries. The age bar is a legal means to understand 'childhood' images in different cultures. For further specifications, countries have age bar on consumption of alcohol, marriages and sexual consent. All these aspects are important to understand the varying degrees 
and factors that govern the genre. Irrespective of language differences across the world, there is a common belief according to which children's literature as a genre is defined on the basis of use of language and writing style for the intended readers.

\section{The Text}

"Fantastic Mr. Fox" by Roald Dahl was first published in the year 1970. The 1996 edition was published with illustrations by Quintin Blake whereas earlier editions had illustrations by Donald Chaffin and then by Jill Benett. The publishing house; George Allen \&Unwin published the 1970 edition, Puffin books by Penguin Group published it in 1974. The text translation has been done directly from the 2007 edition by Puffin books with illustrations by Quintin Blake. The story was also adapted by Wes Anderson into a film which released in 2009 by the same title.

The plot of the novel revolves around a fox who steals livestock from three evil farmers to feed his own family. The character of the fox is anthropomorphic, in fact all the animal characters in the novel attribute humanly emotions and character. This use of anthropomorphic animals is what especially makes the text a children's novel. The story is an adventure tale of Mr. Fox's battle against the three farmers; Boggis, Bunce and Bean who seek the fox and his family to kill them.

Especially important to note was the author's contribution to the genre in weaving stories that don't necessarily confirm to the grammatical framework of English language but make complete sense to the young readers. An initial concern is aroused regarding the non-conformation to the grammatical rules by the author. As the readers are still learning how to read and write in the language, the text might misdirect their 
linguistic skills. Nevertheless, the stories inherit a phonetic quality that catches the attention of the youngsters, the use of fiction and fantastical further enhances their imagination.

\section{Foreignization and Domestication: Addressing the Cultural Turn}

Expressive forms for instance; music, art, dance, ritual and technological forms like clothing, cooking, tool usage, shelter are common forms of assessing culture and cultural differences. Roald Dahl's novels for children draw fictional, fable like worlds but the allegorical undertone inherits heavily from his British heritage. The illustrator of his novels, Quentin Blake draws a picture of the protagonist fox, dressed in a coat and bow tie. The cultural references are not limited to language, the costume, and culinary experiences, geographical landscape are all European.

In the context of children's literature where the texts are didactic, the 'foreignness' of translated text is additionally helpful for the readers. But the 'foreignization' technique might go to the length of transforming the text to an extent where the child readers suffer from lack of relativity affecting their comprehension and understanding. A balance between the domestic and foreign needs to be achieved where the reader not only understands the text but also learns the differential cultural practises and values.

In 1995 Lawrence Venuti described the translation practice which defined and gave prior attention to the 'cultural dynamics' of the text. The translation strategy of domestication and foreignization was discussed in his book The Translator's Invisibility: A History of Translation.

Riita Oittinen (2014) explains the strategies in the light of Children's texts: 
"While domestication assimilates texts to target linguistic and cultural values, in foreignization some significant traces of the original text are retained" (35).

Domestication strategy aims to minimize the 'foreignness' of the source text in its translated form for the target readers, it is contested by theorists like Eugene Nida that it also reforms the text to serve the 'purpose' of the text.

Venuti on the other hand insisted on retaining the 'foreignness'. The propagators of 'foreignization technique' aim to not only to retain the 'foreign' but also the author's impression of the source text instead of transforming the text. Susan Bassnett (1990), a Comparative literature scholar remarked that Lawrence Venuti's translation strategy is 'translator-centred'. His idea of translation strategy aims to 'send the reader abroad'. Instead of adhering to receiving culture's value system for a fluent translated text, foreignization highlights the cultural and linguistic differences.

Domestication also implies a 'fluent' text which adheres to the contemporary language usage (of the time the text is being translated) of the target language. The criticism of domestication is based on translation of texts to English, which according to Venuti (2017) is based on 'submission'. The translation erases the traces of source text and transforms it to a text based on the 'receiving' culture's values.

The ambivalent nature of early literature in Hindi, aimed to reach audience of all age groups. In plays like Raja Harishchandra, children and adults enjoyed and learned based on their ability of comprehension. A similar ambivalence is integral to children's literature, which tries to appeal first to the 'guardian' filters like parents, teachers, guides, publishers before reaching the younger generation. Translation of such texts requires an understanding of this 'ambivalent' feature 
integral to the genre. A translator who wishes to bridge the cultural gaps between two linguistic systems using language tools aims to rewrite the foreign text into a relatable text for target audience. The 'hidden' readers as Isabel Pascua Febles (2006: 111-121) discusses in Translating Cultural References requires implementation of not one strategy but multiple tactics because of the contextual elements that define the genre.

The key to understanding the different approaches in adapting domestication and foreignization in Children's literature translation is how the translator looks at the 'reading audience'. Based on their assumptions and understanding of the target readers, they tend to choose retention or rewriting or adapting terms and taboos too. Hence, the cultural impact on the translator also governs the choices he/she makes in order to translate. The translators who do choose to retain and preserve the 'foreign' do so in order to introduce the readers to the cultural differences and bring them into contact with the 'newness' via the process of translation, as Jan Van Collie also notes in the case of Character name translation. Isabela Pascua (2006) calls this kind of translation strategy 'intercultural education'. Such translations encourage the youngsters to accept differences and diversity in separate cultures and provide a platform where there is exposure to the 'international' literary cannon. Pascua (2006) calls it a new educational policy...needed to overcome so much hostility toward the foreign, the strange, 'the other'.

\section{Translating Food}

Food is an integral part of one's cultural identity; it highlights not only the region's flora and fauna but also the history and economic condition. Roald Dahl in the story describes big, ceiling touching sections of meat and vegetables in underground storage houses which can be sufficient for the 
Fox's family and his friends for a lifetime. He draws a rather enticing picture of excellent pieces of meat in abundance and unlimited storage of apple cider. Food is the theme of this novel; it is the fight to feed ones' family. The descriptions of British cuisine are not completely alien to the readers from other parts of the world nonetheless translating food is challenging as the meat cuts are not part of majority diet in the target language reading audience's region.

The three farmers in the story own big farms where they raise livestock like chickens, turkey, ducks, geese and pigs. The food described is not familiar to the Indian culinary practises. It is English cuisine that the author derives his reference from. At the very outset, one notes that the three characters, Boggis, Bunce and Bean are called farmers. Literal translation of farmer in Hindi is kisan. However, if one was to ask what kisan means to any Hindi speaker, the direct reference is reduced to cultivator of crops. For the lack of better umbrella term for the occupation the term used was 'kisan'. While translating the items, the translation can either choose to provide equivalents of food which are prevalently relished in the Indian subcontinent or to replace it with a single term; 'meat' is used as an umbrella term in modern Hindi and borrowed directly from English. Another way of translating the terms could be transliteration, retaining the foreign-ness of the source text.

Children's literature is known to have a didactic function, in fact, the genre's literature function was limited to this before the twentieth and twenty first century philosophical discourse seeped into criticism and study of children's literature. As a source of knowledge in the allegorical form of a fantastical tale, children's literature not only imparts the knowledge of unknown regions around the world, it is a rich source of cultural and linguistic understanding. 
Sushmita Pareek

The strategy of foreignization was adapted; edibles in the text were retained and transliterated in the Hindi script. Instances where there was an equivalent present in Hindi conversational language, it was used.

\begin{tabular}{|c|c|c|c|}
\hline $\begin{array}{l}\text { S. } \\
\text { No. }\end{array}$ & $\begin{array}{c}\text { Food Item : } \\
\text { English Source } \\
\text { text }\end{array}$ & Translation: Hindi & Transliteration \\
\hline 1 & Dumplings & $\begin{array}{l}\text { डम्टि्लंग्स (मैदा, मीट } \\
\text { और सब्ज़ियो की } \\
\text { पिंडियाँ जो भाप में } \\
\text { पकाई जाती हैं) }\end{array}$ & $\begin{array}{l}\text { damplings } \quad \text { (maidā, } \\
\text { mīt aur } \\
\text { sabziyo kī piṇdiyān̆n } \\
\text { jo bhāp } \\
\text { meñ pakāī jātī haiñ) }\end{array}$ \\
\hline 2 & Doughnuts & $\begin{array}{l}\text { डोनट्स (गोल आकार } \\
\text { का आटे से बना } \\
\text { पकोड़ा जो आम तौर } \\
\text { पर मीठा होता है) }\end{array}$ & $\begin{array}{l}\text { ḍonaț (gol ākār kā } \\
\text { àțe se banā } \\
\text { pakodā jo ām taur par } \\
\text { mīṭhā } \\
\text { hotā hai) }\end{array}$ \\
\hline 3 & Boiled chicken & उबला चिकन & ubalā chikan \\
\hline 4 & Smoked hams & $\begin{array}{l}\text { हेम (अंगारे के धुएं में } \\
\text { पकी सूअर की टांग) }\end{array}$ & $\begin{array}{ll}\text { hem (aṅgāre } & \text { ke } \\
\text { dhueñ men } & \\
\text { pakī sūar kī tāñg) } & \end{array}$ \\
\hline 5 & Sides of bacon & $\begin{array}{l}\text { बेकन (सूअर के कुक्ष } \\
\text { का मीट) }\end{array}$ & $\begin{array}{l}\text { bekan (sūar ke kukṣ } \\
\text { kā mîț) }\end{array}$ \\
\hline 6 & $\begin{array}{ll}\begin{array}{l}\text { Apple } \\
\text { vinegar }\end{array} & \text { cider } \\
\end{array}$ & सेब का सिरका & seb kā sirakā \\
\hline 7 & Plucked chicken & $\begin{array}{l}\text { चिकन अथवा मुर्गी } \\
\text { (पंख साफ़ करके, } \\
\text { पकाने के लिए तैयार } \\
\text { मुर्गी का मीट) }\end{array}$ & $\begin{array}{l}\text { chikan athavāmurgī } \\
\text { (pañkh } \\
\text { sāph karake, pakāne } \\
\text { ke liye } \\
\text { taiyār murgī kā mīṭ) }\end{array}$ \\
\hline 8 & Plucked goose & $\begin{array}{l}\text { गीज़ का मीट (पंख } \\
\text { साफ़ करके, पकाने के } \\
\text { लिए तैयार गीज़ का } \\
\text { मीट)* }\end{array}$ & $\begin{array}{ll}\text { gīz kā mīṭ } & \text { (pañkh } \\
\text { sāph karake, pakāne } \\
\text { ke lie taiyār gīz kā } \\
\text { mịt)* }\end{array}$ \\
\hline
\end{tabular}


Translating Roald Dahl's Fantastic Mr. Fox to Hindi: ...

\begin{tabular}{|l|l|l|l|}
\hline 9 & Plucked duck & बत्तख का मीट (पंख & battakh kā mīṭ (pañkh \\
& & $\begin{array}{l}\text { साफ़ करके, पकाने के } \\
\text { sâph karake, pakāne } \\
\text { ke lie taiyār battakh } \\
\text { लिए तैयार बत्तख का } \\
\text { kā mî̀t) } \\
\text { मीट) }\end{array}$ & \\
\hline
\end{tabular}

Table 1: Translating food items to Hindi

The text, Fantastic Mr. Fox was first located and categorised based on the genre, writing style and reading audience. The task of locating the text was the first step in order to understand the use of language, literary devices and sociocultural setting. It simplified the translation process by identification of similar tropes and trends in the categorised 'children literature' genre in Hindi language. Analysis of 'chronotope-ical' (as understood in Bakhtin's time-space context) of the text as published first in England show the change and difference with its translated Hindi text. The Hindi target text is translated roughly half a century later for young readers mainly from northern region of India (including Rajasthan, Haryana, and Uttar Pradesh where Hindi is the lingua franca).

The vast difference between socio-cultural settings of the two linguistic groups (the speakers and readers belonging to different continents); introduce the 'foreign' through translated texts. Hence, Lawrence Venuti's approach of 'sending the reader abroad' which concentrates on introducing and teaching target text readers about the 'foreign' is used as a didactic form for the text translation (in Hindi). While, the strategy of foreignization and domestication is utilised with the aspect of 'foreignness' highlighted as the two languages in the present study belong to very different backgrounds. The two terms are used as a scale to analyse the retention and replacement factor in the text. The strategy is especially important in analysing the translation of cultural universals like food which is generally 
unique to the region the language belongs to. Out of ten food items in the text, only the term apple cider vinegar called 'Seb ka Sirka' was a part of culinary vocabulary in Hindi.

Although the names of the dishes and ingredients are cooked in certain parts of the non-vegetarian regions where Hindi is the lingua franca. The dishes are described in form of its procedure of preparation or ingredients that are used. For example, smoked hams and sides of bacon are just described as the meat of pig (with body part specifications) that is; 'Suar ka meat' or 'Suar ka Mans'. 'Suar' is the Hindi term for pigs. Lawrence Venuti's strategy is helpful in cultural analysis of translated text. The term meat has been directly adopted in Hindi vocabulary from English language. Another term used for meat is 'gosht' which is Urdu and regularly used in Hindi as well. Similarly, Chicken is an English term which is used for the meat of hen, cock, a little chick hatched from hen's eggs and cooked dishes prepared using meat of hen or cock. The term has been adopted in Hindi dictionary although the literal translation is hatchlings of hen. However, in case of geese and ducks the term in Hindi is battakh for both. Since, both have been described separately in the book the term Geese was retained in Hindi to separate it from Duck meat (battakh ka meat).

\section{Conclusion}

Children's literature in translation tops the list of most translated texts in the world, signifying the importance of special translation theoretical framework for such texts. Topping the list of most translated works is; The Adventures of Pinnochio (1881-83) by Carlo Collodi which was originally written in Italian, it is closely followed by Alice's Adventure in Wonderland by Lewis Carol (originally written in English in 1865) and Adventures of Asterix by Rene Goschinny and Albert Uderzo (originally written in French in 1959). 
The cultural and linguistic challenges of translating Roald Dahl's novel from English to Hindi are numerous from differing literary forms of the two languages to the differing status of the languages within the world history. The study cannot be limited to the text and its translation, the histories of the two languages, the concept of childhood and children's literature have an important role in how the target text is translated, published and received. In Location of Culture, Homi Bhabha (2012), remarks "the emerging global reality, a new international space where great numbers of people have come to live in a state of in-betweenness, endlessly negotiating between the familiar and the unfamiliar, the unknown and the other." The research locates the translation as not a complete domestication or foreignization but the translated text as a part of the "in-betweenness" a "hybrid" of the history of the cultures and languages.

\section{Acknowledgement:}

I would like to thank Prof. J. Prabhakar Rao for his guidance and final review of the research. His supervision was extremely helpful.

\section{References}

BABBITT, N. 1973. Happy endings? Of course, and also joy.In Haviland, V. (ed.), Children and Literature: Views and Reviews. London: Scot, Foresman \& Company.

BAKhtin, Mikhail M. 2002. Forms of Time and of the Chronotope in the Novel: Notes toward a Historical Poetics. In Brian Richardson (ed.), Narrative Dynamics: Essays on Time, Plot, Closure, and Frames.15-24. Columbus: The Ohio State University Press.

BASSNETT SUSAN, \& ANDRÉ LEFEVERE (eds.). 1990. Translation, History and Culture. London: Pinter Publishers. 
Bнавна, Hомі K. 2012. The Location of Culture. New York: Routledge.

Blake, William. 1998. Songs of Innocence and of Experience, vol. 5. New Jersey: Princeton University Press.

Borges, Jorge LuIS. 2000. The Translators of the Thousand and One Nights. In Lawrence Venuti (ed.), The Translation Studies Reader. 34-48. New York: Routledge,

Dahl, RoAld. 2007. Fantastic Mr Fox. London: Penguin.

HoFFMANN, ERnst THEODOR AMADEUS. 2007. The Nutcracker and the Mouse King. London: Penguin.

Hunt, Peter. 2004. International Companion Encyclopedia of Children's Literature. New York: Routledge.

LOCKE, JOHN. 1860. An Essay Concerning Human Understanding and a Treatise on the Conduct of the Understanding. Philadelphia: Hayes \& Zell.

OITTINEN, RIITTA. 2014. On the Ethics of Translating for Children. In Van Coillie, J., \& Verschueren, W. P. (eds.), Children's Literature in Translation: Challenges and Strategies. New York: Routledge.

PASCUA-FEBLES, ISABEL. 2006. Translating Cultural References. In Van Coillie, J., \& Verschueren, W. P. (eds.), Children's Literature in Translation: Challenges and Strategies. 111-121. New York: Routledge.

RUDD, DAVID (ed.). 2012. The Development of Children's Literature. The Routledge Companion to Children's Literature. 19-29. New York: Routledge.

VenUTI, LAWRENCE. 2017. The Translator's Invisibility: A History of Translation. New York: Routledge.

$* * *$

\section{Cite this Work:}

PareeK, Sushmita. 2020. Translating Roald Dahl's Fantastic Mr. Fox to Hindi: A Case Study of Translated Children's Literature. Translation Today, Vol. 14(2). 119-134. DOI:10.46623/tt/2020.14.2.ar7 